\title{
Mutants of Escherichia coli K12 with Defects in Anaerobic Pyruvate Metabolism
}

\author{
By M. C. PASCAL, ${ }^{1 *}$ M. CHIPPAUX, ${ }^{1}$ A. ABOU-JAOUDÉ, ${ }^{1}$ \\ H. P. BLASCHKOWSKI ${ }^{2}$ AND J. KNAPPE ${ }^{2}$ \\ ${ }^{1}$ Laboratoire de Chimie Bactérienne C.N.R.S., 31 chemin Joseph Aiguier, \\ 13274 Marseille Cedex 2, France \\ ${ }^{2}$ Institut für Biologische Chemie der Universität Heidelberg, D-69 Heidelberg, \\ Federal Republic of Germany
}

(Received 1 March 1980; revised 22 September 1980)

\begin{abstract}
A strain of Escherichia coli with a mutation in the ana gene was shown to lack acetaldehyde dehydrogenase and alcohol dehydrogenase. The requirement of this strain for an external oxidant to grow anaerobically on glucose shows that the reduction of acetyl-CoA is the principal means of reoxidation of NADH produced during glycolysis in $E$. coli. Further mutants derived from the ana strain were shown to be affected in the enzymes involved in the fermentation of pyruvate (pyruvate formate-lyase, phosphotransacetylase, acetate kinase). A gene controlling acetate kinase $(a c k B)$ activity has been located at $39 \mathrm{~min}$ on the chromosomal map. Evidence is presented that anaerobic nitrite reduction with pyruvate involves at least the dehydrogenase subunit of the pyruvate dehydrogenase complex.
\end{abstract}

\section{INTRODUCTION}

When nitrate or nitrite is present during the anaerobic growth of Escherichia coli, it is used as electron acceptor for the reoxidation of the NADH produced during glycolysis. The presence of an exogenous electron acceptor, however, is not required for growth, since this organism is able to balance fermentation with endogenous electron acceptors produced by glycolysis. In the scheme of pyruvate metabolism given in Fig. 1, pyruvate formate-lyase (PFL) is thought to be functional in anaerobiosis (Knappe et al., 1972) while the pyruvate dehydrogenase complex (PDH; pyruvate dehydrogenase plus dihydrolipoamide acetyltransferase plus dihydrolipoamide dehydrogenase) is only active in the presence of oxygen (Hansen \& Henning, 1966).

We have isolated a mutant of $E$. coli which required nitrate or nitrite as an exogenous electron acceptor for anaerobic growth (Casse et al., 1976). Although the biochemical basis of this mutation (ana) was not resolved, its existence made possible the selection of a variety of secondary mutants which were unable to grow on glucose plus nitrite ( $\left.\mathrm{Nir}^{-}\right)$. One group (group B) of these $\mathrm{Nir}^{-}$mutants was able to produce hydrogen from formate but not from pyruvate, thus suggesting a common defect in pyruvate formate-lyase (Abou-Jaoude et al., 1978). The aim of the work described in this paper was to identify the nature of the original ana mutation, to characterize more fully the mutants belonging to group B and to elucidate the role of pyruvate in anaerobic nitrite and nitrate reduction in $E$. coli.

Strains. The strains used are listed in Table 1. $\mathrm{Nir}^{-}$phenotypes of strains LCB26, LCB130, LCB 190 and LCB197 are due to mutations in genes distinct from $p f l$ or ack genes. We will designate as nirG the nir gene 
Table 1. Escherichia coli strains used

\begin{tabular}{|c|c|c|c|}
\hline Strain & $\operatorname{Sex}$ & Genotype & Source or method of isolation \\
\hline C600 & $\mathrm{F}^{-}$ & thr-1 leu-6 lacY1 tonA22 thi-1 str & \\
\hline $\mathrm{P} 4 \mathrm{X}$ & $\mathrm{Hfr}$ & $\operatorname{met} B l(\lambda)^{+}$ & \\
\hline AB3295 & $\mathrm{F}^{-}$ & $\begin{array}{l}\text { pabB3 his-4 ilvC7 argE3 thi-l } x y l-5 \\
\text { strA } 704\end{array}$ & A. J. Pittard \\
\hline K63 & $\mathrm{F}^{-}$ & his-1 fadD88 man-1 gal-3 str & G. Novel \\
\hline A2T3 & $\mathrm{F}^{-}$ & aceE2 trpE & J. R. Guest \\
\hline LCB26 & $\mathrm{F}^{-}$ & $\begin{array}{l}\text { thr-1 leu-6 lacYl tonA22 thi-l ana-I } \\
\text { str nirE } 26 \text { facA } 26\end{array}$ & $\begin{array}{l}\text { Abou-Jaoudé et al. (1978), Abou-Jaoudé } \\
\text { (1979) }\end{array}$ \\
\hline LCB49 & $\mathrm{F}^{-}$ & thr-I lacY1 tonA22 thi-1 aceE2 str & $\begin{array}{l}\text { Transduce C } 600 \text { with P1 propagated on } \\
\text { A2T3. Select Leu }{ }^{+} \text {. Screen for Ace } \text { Ace }^{-}\end{array}$ \\
\hline LCB90 & $\mathrm{Hfr}$ & thr-I leu-6 ackB nirG ana-I & $\begin{array}{l}\text { Conjugate P4X with LCB 190. Select } \mathrm{Lac}^{+} \\
\mathrm{Met}^{+} \text {. Screen for Ack }{ }^{-}, \mathrm{Nir}^{-} \text {and } \mathrm{Hfr}\end{array}$ \\
\hline LCB 129 & $\mathbf{F}^{-}$ & $\operatorname{aro} A-2 p f l-1$ & M. C. Pascal \\
\hline LCB 130 & $\mathrm{~F}^{-}$ & $\begin{array}{l}\text { thr-I leu-6 lacYl tonA } 22 \text { thi-1 ana-1 } \\
\text { str pfl-130 nir-130 }\end{array}$ & Abou-Jaoudé et al. (1978) \\
\hline LCB 190 & $\mathrm{~F}^{-}$ & $\begin{array}{l}\text { thr-I leu-6 lacYl tonA22 thi-I ana-I } \\
\text { str ackB nirG }\end{array}$ & $\begin{array}{l}\text { Abou-Jaoudé el al. (1978), Abou-Jaoudé } \\
\text { (1979) }\end{array}$ \\
\hline LCB 197 & $\mathrm{~F}^{--}$ & $\begin{array}{l}\text { thr-1 leu-6 lacY1 tonA22 thi-1 ana-1 } \\
\text { str pfl-197 nirH }\end{array}$ & $\begin{array}{l}\text { Abou-Jaoudé et al. (1978), Abou-Jaoudé } \\
\text { (1979) }\end{array}$ \\
\hline LCB522 & $\mathrm{F}^{-}$ & $\begin{array}{l}d s d A \text { aroC purF argF thi-l str xyl mtl } \\
\text { gal lac }\end{array}$ & E. McFall \\
\hline $723-4$ & $\mathrm{~F}^{-}$ & his-1 fadD88 man-l ackB nirG ana-l & $\begin{array}{l}\text { Conjugate LCB90 with } \mathrm{K} 63 \text {. Select } \mathrm{Gal}^{+} \\
\mathrm{Thr}^{+} \mathrm{Leu}^{+} \text {. Screen for } \mathrm{Ack}^{-}, \mathrm{Nir}^{-}\end{array}$ \\
\hline LCB898 & $\mathrm{F}^{-}$ & thr-1 leu-6 lacY1 tonA22 thi-1 pfl-1 str & S. Varenne \\
\hline LCB 900 & $\mathrm{~F}^{-}$ & thr-1 leu-6 lacYl tonA22 thi-1 ana-1 str & F. Casse \\
\hline
\end{tabular}

affected in strain LCB190 and located at $39 \mathrm{~min}$, and as nirH the nir gene impaired in strain LCB197 and mapping at 19 min (Abou-Jaoudé. 1979).

Growth conditions. The minimal medium was that described by Kelmers et al. (1971) supplemented with $0.02 \%$ $(\mathrm{w} / \mathrm{v})$ leucine, $0.02 \%(\mathrm{w} / \mathrm{v})$ threonine and $0.004 \%(\mathrm{w} / \mathrm{v})$ thiamin. Bacteria were grown with $2 \%(\mathrm{w} / \mathrm{v})$ glucose at $\mathrm{pH} 7$ and $37^{\circ} \mathrm{C}$, harvested from mid-exponential phase and stored as a cell paste at $-90^{\circ} \mathrm{C}$. For anaerobic growth the media were flushed with nitrogen and the $\mathrm{pH}$ was kept constant by addition of $\mathrm{NaOH}$ through a $\mathrm{pH}$-stat. For studies of anaerobic growth on pyruvate $(1 \%, \mathrm{w} / \mathrm{v})$, the medium was inoculated with 0.01 vol. of a mid-exponential phase culture grown aerobically with glucose. Growth was followed for at least $36 \mathrm{~h}$.

Bacteria used for the determination of nitrate and nitrite reduction were grown as described by Abou-Jaoudé $e t$ al. (1978). The media contained either glucose $\left(0.2 \%\right.$, w/v) plus $\mathrm{KNO}_{3}(0 \cdot 1 \%$, w/v) or glycerol $(0 \cdot 2 \%$, w/v) plus $\mathrm{KNO}_{2}(0 \cdot 01 \%, \mathrm{w} / \mathrm{v})$.

Measurement of enzyme activities. A suspension of bacteria $(5 \mathrm{~g})$ in $15 \mathrm{ml} 50 \mathrm{~mm}$-potassium 3-( $N$-morpholino)propanesulphonate (MOPS) buffer $\mathrm{pH} 8\left(\mathrm{~K}^{+}\right.$is essential for the stabilization of phosphotransacetylase) was subjected to sonication (Branson Sonifier type S75) for $75 \mathrm{~s}$ at 0 to $10^{\circ} \mathrm{C}$ and centrifuged at $30000 \mathrm{~g}$ for $1 \mathrm{~h}$. The supernatant fraction contained 25 to $30 \mathrm{mg}$ protein $\mathrm{ml}^{-1}$ (determined by the Biuret method). For the determination of pyruvate formate-lyase, centrifugation was at $140000 \mathrm{~g}$ for $90 \mathrm{~min}$ (to pellet the pyruvate dehydrogenase complex).

Aldehyde dehydrogenase lacetaldehyde: $\mathrm{NAD}^{+}$oxidoreductase (CoA-acylating); EC 1.2.1.10] was assayed as described by Stadtman \& Burton (1955) using 0.1 M-potassium phosphate buffer pH 7 (Rudolph et al., 1968). Alcohol dehydrogenase [alcohol: $\mathrm{NAD}^{+}$oxidoreductase; EC 1.1.1.1] activity was measured in anaerobic cuvettes under argon (to prevent NADH oxidation). The assay mixture $(1 \mathrm{ml})$ contained $50 \mu \mathrm{mol}$ MOPS $\mathrm{pH} 8$, $0.4 \mu \mathrm{mol} \mathrm{NAD}, 6 \mu \mathrm{mol}$ dithiothreitol and $0.1 \mu \mathrm{mol}\left(\mathrm{NH}_{4}\right)_{2} \mathrm{Fe}\left(\mathrm{SO}_{4}\right)_{2}$. After preincubation for $30 \mathrm{~min}$ the cell extract $(0.3$ to $1.5 \mathrm{mg}$ protein) was added and NADH absorption was observed for several minutes prior to the addition of $10 \mu \mathrm{l} \quad 1 \mathrm{M}$-acetaldehyde. $\mathrm{D}(-)$-Lactate dehydrogenase $/ \mathrm{D}$-lactate: $\mathrm{NAD}^{+}$oxidoreductase; EC 1.1.1.28| was determined according to Tarmy \& Kaplan (1968), acetate kinase |ACK; ATP:acetate phosphotransferase; EC 2.7.2.1I was determined according to Rose (1955), and phosphotransacetylase |PTA; acetyl-CoA : orthophosphate acetyltransferase; EC 2.3.1.8I was measured by the coupled spectrophotometric assay described by Blaschkowski et al. (1979).

Pyruvate formate-lyase |PFL; acetyl-CoA:formate $C$-acetyltransferase; EC 2.3.1.54], which occurs in interconvertible active and inactive forms (Knappe et al., 1972: Knappe, 1978), was measured as follows. The cell extract ( 2 to $5 \mathrm{mg}$ protein), containing PFL predominantly in the inactive state, was supplemented with $50 \mu \mathrm{g} P F$ 
activase and subjected to the activation process for $30 \mathrm{~min}$. The procedure described by Knappe et al. (1974) was followed but using Tris buffer $\mathrm{pH} 7.2$ and photoreduced 5-deazariboflavin (10 $\mu \mathrm{M})$ as the reductant instead of the flavodoxin-chloroplast system. PFL activity was subsequently determined by the coupled spectrophotometric assay (Knappe et al., 1974).

Pyruvate dehydrogenase complex activity was measured by the method described by Guest \& Creaghan (1973).

All enzyme activities are expressed in terms of $\mu \mathrm{mol}$ substrate transformed $\min ^{-1}(\mathrm{mg} \text { protein })^{-1}$ at $30^{\circ} \mathrm{C}$.

Acetate, $\mathrm{D}(-)$-lactate and glucose in culture media were determined by common enzymic methods (Bergmeyer, 1974).

Measurement of nitrate and nitrite reduction. The formate-nitrate and formate-nitrite reductase activities were determined with whole cells as described previously (Abou-Jaoude et al., 1979). When pyruvate replaced formate, its concentration was $40 \mathrm{~mm}$.

Genetic techniques. Mating and transduction experiments were performed by the methods of Taylor \& Thoman (1964) and Lennox (1955), respectively. The Ack phenotype was tested on solid minimal medium (Davis \& Mingioli, 1950) with acetate $(0.3 \%, \mathrm{w} / \mathrm{v})$ as carbon source. The Pab and Fad phenotypes were tested according to Huang \& Pittard (1967) and Overath et al. (1969), respectively.

\section{RESULTS}

The Ana- mutation affects the enzymes of acetyl-CoA reduction

Various properties of the $\mathrm{Ana}^{-}$strain LCB900 suggested it had a defect in the reoxidation of NADH by the terminal fermentation processes (Chippaux et al., 1974). In E. coli K12 the principal hydrogen acceptor during fermentation of glucose is acetyl-CoA (to form ethanol). Indeed, the two enzyme activities concerned with this process, acetaldehyde dehydrogenase and the accompanying alcohol dehydrogenase (Rudolph et al., 1968; Schmitt, 1975), were found (Table 2) to be absent from the extract of strain LCB900. TThe other alcohol dehydrogenase of E. coli is repressed during growth with glucose (Meyhack et al., 1973).] The $\mathrm{D}(-)$-lactate dehydrogenase activity was similar to that in the parent strain C600 (Table 2).

\section{Mutations affecting the conversion of pyruvate into acetate}

The wild-type (C600) and Ana- (LCB900) strains were both able to grow anaerobically on pyruvate as the sole carbon and energy source with a mean doubling time of 2 to $3 \mathrm{~h}$. Nir mutants of group B, which are unable to produce gas from pyruvate, were found to be unable to grow anaerobically with pyruvate. This prompted an investigation of possible defects in the relevant enzymes - pyruvate formate-lyase (PFL), phosphotransacetylase (PTA) and acetate kinase (ACK). The results (Table 3) indicated that strains LCB 130 and LCB197 were defective only in PFL; PFL activase was found to be unaffected in these two strains. Strains LCB 190 and LCB26 lacked ACK; the latter strain also lacked PTA. During aerobic growth with glucose, ACK-less cells grew slowly and did not accumulate acetate (Table 4). They had also lost the ability to grow aerobically with acetate, a property which was employed in the genetic analysis.

Table 2. Enzyme activities in extracts of cells grown with glucose

\begin{tabular}{|c|c|c|c|c|}
\hline \multirow[b]{2}{*}{ Strain } & \multirow[b]{2}{*}{$\begin{array}{l}\text { Growth } \\
\text { condition }\end{array}$} & \multicolumn{3}{|c|}{ Activity $\left[\mu \mathrm{mol} \mathrm{min}^{-1}(\mathrm{mg} \text { protein })^{-1}\right]$} \\
\hline & & $\begin{array}{c}\text { Aldehyde } \\
\text { dehydrogenase } \\
\text { (ALDH) }\end{array}$ & $\begin{array}{c}\text { Alcohol } \\
\text { dehydrogenase } \\
(\mathrm{ADH})\end{array}$ & $\begin{array}{c}D(-) \text {-Lactate } \\
\text { dehydrogenase } \\
(\mathrm{LDH})\end{array}$ \\
\hline C600 $\left(\mathrm{Ana}^{+}\right)$ & $\begin{array}{l}\text { Aerobic } \\
\text { Anaerobic }\end{array}$ & $\begin{array}{l}0.11 \\
0.5\end{array}$ & $\begin{array}{l}0.08 \\
0.2\end{array}$ & $\begin{array}{l}0.45 \\
1.3\end{array}$ \\
\hline LCB900 $\left(\mathrm{Ana}^{-}\right)$ & Aerobic & 0.0003 & 0.001 & $0 \cdot 30$ \\
\hline
\end{tabular}


Table 3. Enzyme activities in extracts of cells grown aerobically with glucose

For $E$. coli $\mathrm{K} 12$ (ATCC 10798) the pyruvate formate-lyase activities in extracts from aerobically and strictly anaerobically grown cells (glucose, $\mathrm{pH} 7$ ) were 0.5 and $1 \cdot 3$, respectively.

\begin{tabular}{lcccc} 
& \multicolumn{4}{c}{ Activity $\left[\mu \mathrm{mol} \mathrm{min}^{-1}\left(\mathrm{mg} \mathrm{protein}^{-1}\right]\right.$} \\
Strain & $\begin{array}{c}\text { Pcetate } \\
\text { formate-lyase } \\
(\mathrm{PFL})\end{array}$ & $\begin{array}{c}\text { kinase } \\
(\mathrm{ACK})\end{array}$ & $\begin{array}{c}\text { Phospho- } \\
\text { transacetylase } \\
(\mathrm{PTA})\end{array}$ & $\begin{array}{c}\text { Pyruvate } \\
\text { dehydrogenase } \\
(\mathrm{PDH})\end{array}$ \\
LCB900 & 0.52 & 1.6 & 1.3 & 0.075 \\
LCB130 & $<0.02$ & 2.3 & 1.8 & - \\
LCB197 & $<0.02$ & 0.9 & 1.3 & - \\
LCB26 & 0.36 & $<0.01$ & $<0.001$ & 0.065 \\
LCB 190 & 0.37 & $<0.01$ & 1.3 & 0.081
\end{tabular}

Table 4. Aerobic growth of Ana- mutants on glucose

The acetate concentration was determined in the medium after growth under vigorous aeration to a cell mass of $3 \mathrm{~g}$ wet $\mathrm{wt}^{-1}$.

Strain
LCB900 (Ana $\left.{ }^{-}\right)$
LCB130 (Ana $\left.\mathrm{Pfl}^{-} \mathrm{Nir}^{-}\right)$
LCB197( Ana $\left.^{-} \mathrm{Pfl}^{-} \mathrm{Nir}^{-}\right)$
LCB26 (Ana Ack $\left.^{-} \mathrm{Pta}^{-} \mathrm{Nir}^{-}\right)$
LCB190 (Ana Ack $\left.^{-} \mathrm{Nir}^{-}\right)$

$\begin{array}{cc}\begin{array}{c}\text { Doubling time } \\ (\mathrm{min})\end{array} & \begin{array}{c}\text { Acetate production } \\ (\mathrm{mM})\end{array} \\ 60 & 5 \\ 55 & 6 \\ 55 & 5 \\ 110 & <0 \cdot 2 \\ 120 & <0.2\end{array}$

\section{Genetic analysis}

To determine whether the mutations leading to the loss of PFL in strains LCB130 and LCB 197 had affected the $p f$ gene described by Varenne et al. (1975), phage P1-mediated transduction experiments were performed using these strains as donors and a pflaroA strain (LCB 129) as recipient. All the selected $\mathrm{AroA}^{+}$recombinants were unable to produce gas from pyruvate indicating that the $p f l$ gene was affected in both mutants. On the other hand, strains LCB26 and LCB 190 were demonstrated to have an intact $p f l$ gene: when used as donors in the transduction experiments they yielded transductants which, like the parent strain LCB900, produced gas from pyruvate.

For genetic mapping of the $\mathrm{Ack}^{-}$mutation carried by strain LCB 190, an Hfr strain was constructed which carried this mutation. For this purpose, the Hfr strain P4X was mated with a $\lambda$ lysogenic derivative of LCB190; from among the $\mathrm{Lac}^{+} \mathrm{Met}^{+}$recombinants, a strain having received the $\mathrm{F}$ factor and $\mathrm{Ack}^{-}$character was retained. This $\mathrm{Hfr}$ strain, LCB90, was used in subsequent conjugation experiments with strain K63. A strong linkage was observed with his (70\%) and with fadD (62\%). A Fad Ack $^{-}$recombinant (723-4) was used for transduction experiments with strain AB3295 carrying the pabB marker. In a cross where $128 \mathrm{Pab}^{+}$transductants were selected, $\mathrm{Ack}^{-}$and $\mathrm{Fad}^{-}$characters were cotransduced at 4.6 and $6.2 \%$, respectively; moreover, none of the $\mathrm{Ack}^{-}$ transductants were found to be $\mathrm{Fad}^{-}$. In the reciprocal cross where the Ack ${ }^{+}$transductants were selected, $5.4 \%$ had acquired the $\mathrm{Pab}^{-}$character while none was $\mathrm{Fad}^{+}$. From these results we conclude that the gene $a c k B$ affected in strain LCB190 is close to $p a b B$ but resides on the opposite side to $\mathrm{fadD}$, at about $39 \mathrm{~min}$.

Recent studies have located genes ack, pta, facA and facB near purF (Brown et al., 1977; Guest, 1979). Since strain LCB26, like the facA mutants, lacks ACK and PTA activities, transduction experiments were performed with strain LCB26 as donor and strain LCB522 
Table 5. Physiological characteristics of mutants

\begin{tabular}{|c|c|c|c|c|c|c|}
\hline \multirow[b]{3}{*}{ Strain } & \multicolumn{6}{|c|}{ Activity $\left[\mu \mathrm{mol}\right.$ substrate reduced $\left.\min ^{-1}(\mathrm{mg} \text { cells })^{-1}\right]$} \\
\hline & \multicolumn{2}{|c|}{ Nitrate reductase } & \multicolumn{2}{|c|}{ Nitrite reductase } & \multicolumn{2}{|c|}{ Gas production } \\
\hline & $\begin{array}{c}\text { With } \\
\text { pyruvate }\end{array}$ & $\begin{array}{c}\text { With } \\
\text { formate }\end{array}$ & $\begin{array}{c}\text { With } \\
\text { pyruvate }\end{array}$ & $\begin{array}{c}\text { With } \\
\text { formate }\end{array}$ & $\begin{array}{c}\text { With } \\
\text { pyruvate }\end{array}$ & $\begin{array}{c}\text { With } \\
\text { formate }\end{array}$ \\
\hline LCB900 $\left(\right.$ Ana $\left.^{-}\right)$ & 0.037 & 0.135 & 0.031 & 0.024 & + & + \\
\hline LCB898 $\left(\mathrm{Pfl}^{-}\right)$ & 0.027 & 0.195 & 0.033 & 0.022 & - & + \\
\hline LCB49 $\left(\mathrm{Pdh}^{-}\right)$ & $<0.001$ & 0.225 & $<0.001$ & $0 \cdot 106$ & + & + \\
\hline LCB $130\left(\mathrm{Ana}^{-} \mathrm{Pft}^{-} \mathrm{Nir}^{-}\right)$ & 0.024 & 0.057 & 0.034 & 0.030 & - & + \\
\hline LCB $197\left(\mathrm{Ana}^{-} \mathrm{Pfl}^{-} \mathrm{Nir}^{-}\right.$) & 0.075 & 0.075 & 0.013 & $<0.001$ & - & + \\
\hline LCB26 (Ana- ${ }^{-}$Ack $\left.^{-} \mathrm{Pta}^{-} \mathrm{Nir}^{-}\right)$ & 0.006 & 0.084 & 0.012 & 0.043 & - & + \\
\hline LCB $190\left(\right.$ Ana $^{-}$Ack $\left.^{-} \mathrm{Nir}^{-}\right)$ & 0.001 & 0.091 & 0.003 & 0.011 & - & + \\
\hline
\end{tabular}

(aroC purF) as recipient. Among the $200 \mathrm{Pur}^{+}$recombinants selected, $49.5 \%$ were Ack $^{-}$, while only $6 \%$ of the 100 Aro $^{+}$recombinants selected had acquired this phenotype. These results are in agreement with those reported by Guest (1979) for facA mutations.

\section{Pyruvate as electron donor for nitrate and nitrite reduction}

The $\mathrm{Nir}^{-}$strains of group $\mathrm{B}$ are devoid of NADH-nitrite oxidoreductase activity (Abou-Jaoudé, 1979) but can reduce nitrate and nitrite when using formate as electron donor (Abou-Jaoudé et al., 1978), with the exception of LCB197 (which carries a nirH mutation and so is defective in nitrite reduction due to the lack of cytochrome $c$-552). Since these strains which cannot produce formate display a reduced but significant nitrite reduction with glucose (Abou-Jaoudé et al., 1978), intermediate donors other than NADH or formate have been investigated. Using resting cells, nitrite (or nitrate) reduction was observed with the parental strain LCB900 when pyruvate was the electron donor. Although strain LCB898 lacked PFL activity and thus did not produce formate, it could still use pyruvate for nitrite or nitrate reduction (Table 5). A strain carrying a defect in the dehydrogenase subunit of the pyruvate dehydrogenase complex (LCB49) was unable to utilize pyruvate, suggesting that the electron transfer between pyruvate and nitrite (or nitrate) proceeds via the pyruvate dehydrogenase system.

\section{DISCUSSION}

During anaerobic growth with glucose at $\mathrm{pH} 7, E$. coli $\mathrm{K} 12$ strains display a fermentation pattern for energy production which principally follows the equation: glucose $\rightarrow 2$ formate + acetate + ethanol (Fig. 1). In this pathway, pyruvate is processed through the pyruvate formate-lyase reaction and regeneration of $\mathrm{NAD}^{+}$occurs only subsequently by reduction of one of the two molecules of acetyl-CoA formed. The importance of acetyl-CoA as terminal hydrogen acceptor and its indispensability as long as pyruvate is processed to acetate as an end-product is immediately evident from the growth property of the Ana- mutant. Despite the fact that it contains $\mathbf{D}(-)$-lactate dehydrogenase, this organism, which lacks acetaldehyde and ethanol dehydrogenases, can only grow when an external oxidant (nitrite or nitrate) is supplied (Casse et al., 1976). However, nitrite or nitrate is no longer required by a further mutant derived from the $\mathrm{Ana}^{-}$strain, which additionally lacks pyruvate formate-lyase (strain LCB 130). This organism, which can grow with glucose provided that acetate is added as the anabolic $\mathrm{C}_{2}$ source, displays pure lactate fermentation for energy production (data not shown). If nitrate or nitrite is the exogenous electron acceptor, NADH supplies electrons to the nitrate or nitrite reductase terminal enzymes through specific transfer chains. 


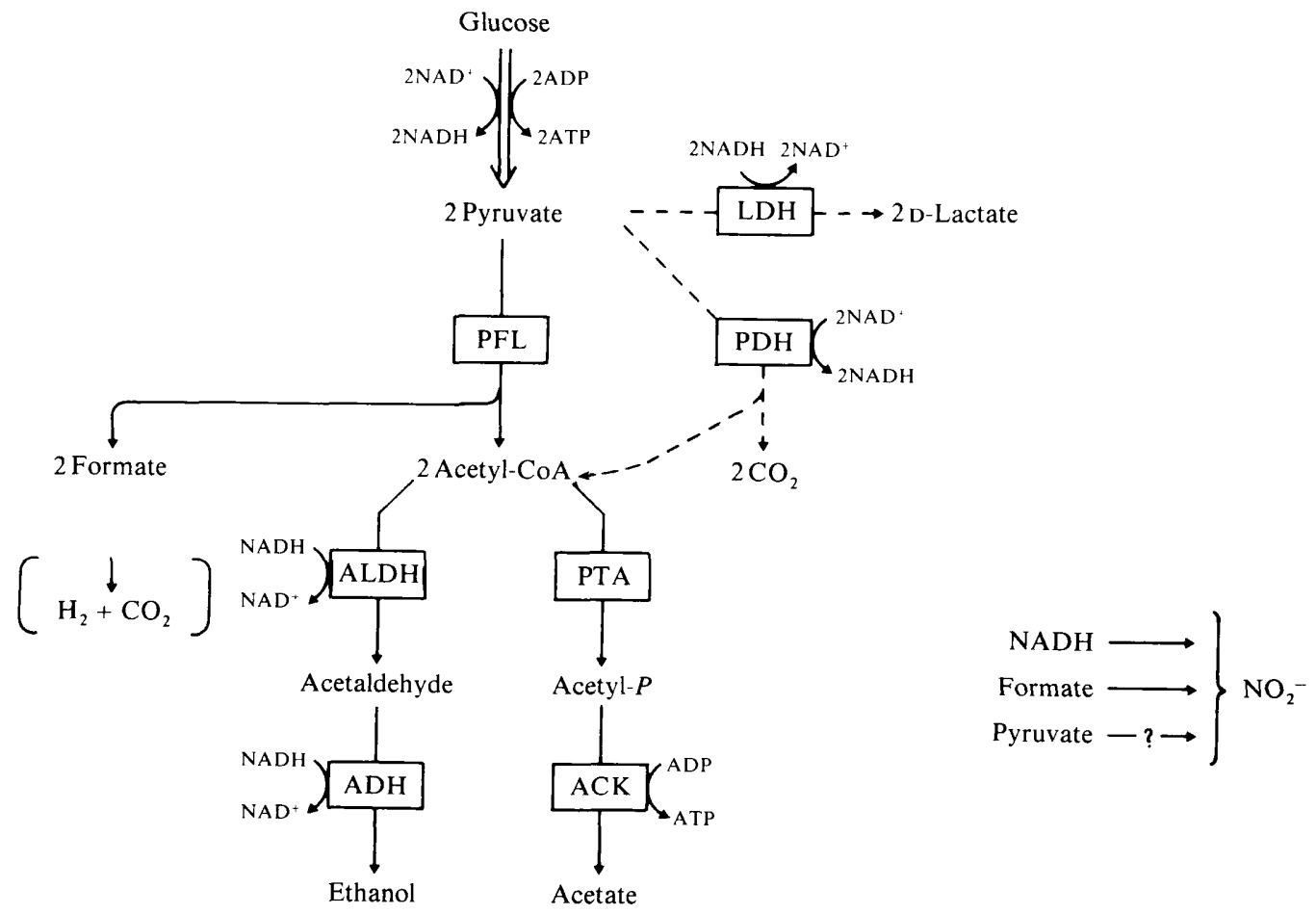

Fig. 1. Glucose fermentation in Escherichia coli K12. Enzyme abbreviations: ACK, acetate kinase; ADH, alcohol dehydrogenase; ALDH, aldehyde dehydrogenase; LDH, D-lactate dehydrogenase; PDH, pyruvate dehydrogenase complex: PFL, pyruvate formate-lyase; PTA, phosphotransacetylase.

The simultaneous defect in alcohol and aldehyde dehydrogenases in the Ana- strain could derive from a mutation in a control gene, from a deletion through adjacent genes or from a polar mutation in an operon; that both enzymes act in sequence could support the existence of a transcription unit. Alternatively, the double defect could be explained by mutations in both structural genes. Since mutants defective in either alcohol or aldehyde dehydrogenase must show the $\mathrm{Ana}^{-}$phenotype, only the biochemical characterization of recombinants could answer the question. It would be of interest to resume the genetic analyses performed by Casse et al. (1976) and to study mutants affected in the structural genes.

The present studies have also revealed that $E$. coli K12, like Proteus rettgeri (Kröger et al., 1974), can grow anaerobically with pyruvate as sole carbon source. Energy is then obtained from pyruvate fermentation to formate and acetate which provides (one) ATP without any redox process. At least one of the enzymes involved in this pathway (pyruvate-formate lyase, phosphotransacetylase or acetate kinase) proved to be affected in the various mutants of the $\mathrm{Nir}^{-}$group B. That strains LCB26 and LCB190, although they contain pyruvate formate-lyase, are unable to produce hydrogen from pyruvate is expected since any continuous pyruvate conversion requires $\mathrm{CoA}$ regeneration from acetyl-CoA and these strains lack both the phosphotransacetylase/acetate kinase (PTA/ACK) and aldehyde dehydrogenase/alcohol dehydrogenase reaction sequences.

The low growth rate and markedly reduced levels of acetate production during aerobic growth of mutants LCB26 and LCB190 indicate that the PTA/ACK reaction sequence also operates during aerobic cell growth with glucose. The growth-promoting effect of PTA and $\mathrm{ACK}$ (by removing acetyl-CoA and enhancing $\mathrm{CoA}$ recycling) could be due to several reasons: several enzymes of the citric acid cycle are subjected to glucose repression (Sanwal, 
1970 ), acetyl-CoA is inhibitory to the pyruvate dehydrogenase complex (Hansen \& Henning, 1966) and acetyl-CoA appears to inhibit hexose transport (Morgan \& Kornberg, 1969). Mutants impaired in ACK and PTA have previously been described (Brown et al., 1977). A comparison of our strain LCB $190\left(\right.$ Ack $\left.^{-}\right)$and strain JM591 (Ack ${ }^{-}$) of these authors revealed that LCB190 is more defective in aerobic growth on acetate or glucose as well as acetate accumulation from glucose. While these differences could possibly be explained by a more severe defect in LCB 190 ( $1 \%$ as compared with $5 \%$ of wild-type activity), the genetic defects appear to differ since ack of JM591 was located at $50 \mathrm{~min}$ on the chromosomal map, whereas that of LCB 190 resides at $39 \mathrm{~min}$. As a result, we have designated the latter mutation $a c k B$. It is so far unclear whether the two ack genes code for two distinct ACK enzymes or control a single enzyme. Genetically and biochemically, strain LCB26 resembles the fac $A$ mutants, i.e. loss of both ACK and PTA activities and cotransduction of the mutation with purF (Guest, 1979). We therefore propose the gene affected in LCB26 to be the facA gene itself.

Resting cells of $E$. coli grown anaerobically in the presence of nitrate or nitrite are able to reduce these acceptors with pyruvate as an electron donor. One could have supposed that formate was an intermediate in this reaction; however, an aceE strain carrying a defect in the dehydrogenase subunit of the pyruvate dehydrogenase complex provided unambiguous evidence that the electrons in fact come from pyruvate via the pyruvate dehydrogenase complex and not from formate via pyruvate formate-lyase and formate dehydrogenase. This would imply that NADH is involved in electron transport between pyruvate and nitrite.

Nevertheless, the involvement of NADH in the electron transfer from pyruvate to nitrite is in contradiction with the fact that strains lacking NADH-nitrite oxidoreductase possess pyruvate-nitrite oxidoreductase activity. This difficulty could be overcome since it has been proposed that the pyruvate dehydrogenase complex of $E$. coli has a site for interaction with an as yet unidentified electron acceptor (Frey et al., 1978). It would be of interest to use a mutant lacking NADH-specific lipoamide dehydrogenase of this complex in order to establish whether or not NADH is involved in the pyruvate-nitrate/nitrite electron transfer.

Anaerobic conditions normally block the pyruvate dehydrogenase complex. This has been ascribed to the inhibitory action of NADH (Hansen \& Henning, 1966). The presence of nitrate or nitrite could shift the NADH/NAD ${ }^{+}$ratio and thus enable the enzyme to be active.

Although strains LCB26 and LCB 190 have normal pyruvate dehydrogenase activity they are unable to reduce nitrate or nitrite with pyruvate. This again can be explained by the inhibitory effect of the accumulated acetyl-CoA.

After the completion of this manuscript, we became aware of the discovery of another mutation, $a d h$, which results in the derepression of alcohol dehydrogenase (Clark \& Cronan, 1980). This mutation appears to map exceedingly close to the ana locus described here.

We are indebted to Dr William W. Kay for helpful comments and suggestions during the preparation of this manuscript. We thank Dr B. Bachmann and Dr J. R. Guest for providing strains.

\section{REFERENCES}

Abou-JaOudE, A. (1979). Etude de la réduction du nitrite chez Escherichia coli K12. Thèse de Doctorat d'Etat, Universite d'Aix-Marseille II, France.

Abou-Jaoudé, A., Pascal, M. C., CASSE, F. \& Chippaux, M. (1978). Isolation and phenotypes of mutants from Escherichia coli $\mathrm{K} 12$ defective in nitrite reductase activity. FEMS Microbiology Letters 3, 235-239.

Abou-Jaoudé, A., Chippaux, M. \& Pascal, M. C. (1979). Formate-nitrite reduction in Escherichia coli $\mathrm{K} 12$. Physiological study of the system. European Journal of Biochemistry 95, 309-314.

Bergmeyer, H. U. (editor) (1974). Methoden der
Enzymatischen Analyse, 3rd edn. Weinheim: Verlag Chemie.

Blaschkowski, H. P., Knappe, J. \& Wieland, Th. (1979). $S$-Ethyl-Coenzyme A and acetonyl-dethioCoenzyme A. Interactions with pyruvate carboxylase and phosphotransacetylase. FEBS Letters 98, 81-84.

Brown, T. D. K., Jones-Mortimer, M. C. \& KornberG, H. L. (1977). The enzymic interconversion of acetate and acetyl-coenzyme $\mathrm{A}$ in Escherichia coli. Journal of General Microbiology 102, 327-336.

Casse, F., Pascal, M. C., Chippaux, M. \& 
RATOUCHNiaK, J. (1976). Genetic analysis of mutants from Escherichia coli unable to grow anaerobically without exogenous acceptor. Molecular and General Genetics 148, 338-340.

Chippaux, M., Casse, F., Pascal, M. C. \& Gray, C. T. (1974). Nitrate and nitrite as electron acceptors in a glycolysis negative mutant of Escherichia coli. Proceedings of the American Society for Microbiology, p. 86.

Clark, D. \& Cronan, J. E. (1980). Mutants of Escherichia coli with altered control of alcohol dehydrogenase and nitrate reductase. Journal of Bacteriology 141, 177-183.

Davis, B. D. \& Mingioli, E. S. (1950). Mutants of Escherichia coli requiring methionine or vitamin B12. Journal of Bacteriology 60, 17-28.

Frey, P. A., IKeda, B. H., Gavino, G. R., SPECKHARD, D. C. \& WoNG, S. S. (1978). Escherichia coli pyruvate dehydrogenase complex. Site coupling in electron and acetyl group transfer pathways. Journal of Biological Chemistry 253, 7234-7241.

Guest, J. R. (1979). Anaerobic growth of Escherichia coli $\mathrm{K} 12$ with fumarate as terminal electron acceptor. Genetic studies with menaquinone and fluoroacetate-resistant mutants. Journal of General Microbiology 115, 259-271.

Guest, J. R. \& Creaghan, I. T. (1973). Gene--protein relationships of the $\alpha$-keto acid dehydrogenase complexes of Escherichia coli $\mathrm{K} 12$ : isolation and characterization of lipoamide dehydrogenase mutants. Journal of General Microbiology 75, 197210.

HANSEN, R. G. \& Henning, U. (1966). Regulation of pyruvate dehydrogenase activity in Escherichia coli K12. Biochimica et biophysica acta 122, 355-358.

HuANG, M. \& PitTARD, J. (1967). Genetic analysis of mutant strains of Escherichia coli requiring $p$ aminobenzoic acid for growth. Journal of Bacteriology 93, 1938-1942.

Kelmers, A. D., Hancher, C. W., Phares, E. F. \& NovelLI, G. D. (1971). Large-scale fermentation of Escherichia coli and recovery of transfer ribonucleic acids. Methods in Enzymology 20, 3-9.

KNAPPE, J. (1978). Pyruvate formate-lyase: mechanism and regulation by interconversion. HoppeSeyler's Zeitschrift für physiologische Chemie 359, 286.

KNAPPE, J., BlaschKowski, H. P.\& EdENHARDER, R. (1972). Enzyme-dependent activation of pyruvate formate-lyase of Escherichia coli. In Metabolic Interconversion of Enzymes, pp. 319-329. Edited by
O. Wieland, E. Helmreich \& H. Holzer. Berlin, Heidelberg \& New York: Springer-Verlag.

KnapPe, J., Blaschkowski, H. P., Grobner, P. \& Schmitt, T. (1974). Pyruvate formate-lyase of Escherichia coli: the acetyl enzyme intermediate. European Journal of Biochemistry 50, 253-263.

Kröger, A., Schimkat, M. \& Niedermaier, S. (1974). Electron transport phosphorylation coupled to formate reduction in anaerobic grown Proteus rettgeri. Biochimica et biophysica acta 347, 273289.

LENNOX, E. S. (1955). Transduction of linked genetic characters of the host by bacteriophage P1. Virology' 1, 190-206.

Meyhack, B., Pfleiderer, G. \& Menningmann, H. D. (1973). Iodoacetic acid resistant alcohol dehydrogenase of an Escherichia coli mutant. European Journal of Biochemistry 33, 19-29.

Morgan, M. J. \& Kornberg, H. L. (1969). Regula tion of sugar accumulation by Escherichia coli. FEBS Letters 3, 53-55.

Overath, P., Pauli, G. \& Schairer, H. U. (1969). Fatty acid degradation in Escherichia coli. An inducible acyl-CoA synthetase, the mapping of old mutations and the isolation of regulatory mutants. European Journal of Biochemistry 7, 559-574.

Rose, J. A. (1955). Acetate kinase of bacteria (acetokinase). Methods in Enzymology 1, 591-595.

Rudolph, F. B., Purich, D. L. \& Fromm, H. J. (1968). Coenzyme A-linked aldehyde dehydrogenase from Escherichia coli. I. Partial purification, properties and kinetic studies of the enzyme. Journal of Biological Chemistry 243, 5539-5545.

SANWAL, B. D. (1970). Allosteric controls of amphi bolic pathways in bacteria. Bacteriological Review's 34, 20-39.

SchmitT, B. (1975). Aldehyde dehydrogenase activity of a complex particle from Escherichia coli. Bio chimie 57, 1001-1004.

Stadtman, E. R. \& Burton, R. M. (1955). Aldehyde dehydrogenase from Clostridium kluyveri. Methods in Enzymology 1, 518-519.

TARMY, E. M. \& KAPlAN, N. O. (1968). Chemical characterization of D-lactate dehydrogenase from Escherichia coli B. Journal of Biochemical Chemistry 243, 2579-2586.

TAYLOR, A. L. \& Thoman, M. S. (1964). The genetic map of E. coli K12. Genetics 50,659-677.

Varenne, S., Casse, F., Chippaux, M. \& Pascal, M. C. (1975). A mutant of Escherichia coli deficient in pyruvate formate lyase. Molecular and General Genetics 141, 181-184. 